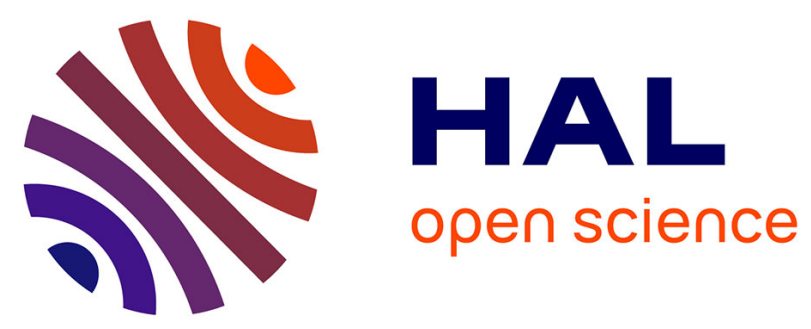

\title{
Use of immunofluorescence technique in cultured fibroblasts from Mediterranean cetaceans as new "in vitro" tool to investigate effects of environmental contaminants
}

Letizia Marsili, Silvia Casini, Daniela Bucalossi, Serena Porcelloni, Silvia

Maltese, Maria Cristina Fossi

\section{To cite this version:}

Letizia Marsili, Silvia Casini, Daniela Bucalossi, Serena Porcelloni, Silvia Maltese, et al.. Use of immunofluorescence technique in cultured fibroblasts from Mediterranean cetaceans as new "in vitro" tool to investigate effects of environmental contaminants. Marine Environmental Research, 2008, 66 (1), pp.151. 10.1016/j.marenvres.2008.02.068 . hal-00501960

\section{HAL Id: hal-00501960 https://hal.science/hal-00501960}

Submitted on 13 Jul 2010

HAL is a multi-disciplinary open access archive for the deposit and dissemination of scientific research documents, whether they are published or not. The documents may come from teaching and research institutions in France or abroad, or from public or private research centers.
L'archive ouverte pluridisciplinaire HAL, est destinée au dépôt et à la diffusion de documents scientifiques de niveau recherche, publiés ou non, émanant des établissements d'enseignement et de recherche français ou étrangers, des laboratoires publics ou privés. 


\section{Accepted Manuscript}

Use of immunofluorescence technique in cultured fibroblasts from Mediterra nean cetaceans as new "in vitro" tool to investigate effects of environmental contaminants

Letizia Marsili, Silvia Casini, Daniela Bucalossi, Serena Porcelloni, Silvia Maltese, Maria Cristina Fossi

PII:

S0141-1136(08)00067-6

DOI: 10.1016/j.marenvres.2008.02.068

Reference: MERE 3219

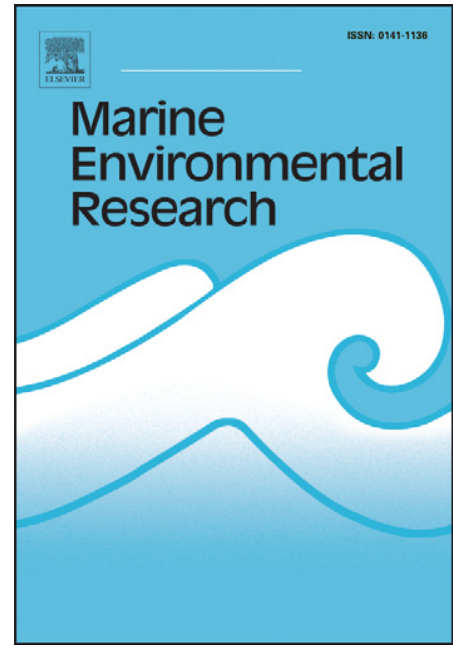

To appear in:

Marine Environmental Research

Please cite this article as: Marsili, L., Casini, S., Bucalossi, D., Porcelloni, S., Maltese, S., Fossi, M.C., Use of immunofluorescence technique in cultured fibroblasts from Mediterranean cetaceans as new "in vitro" tool to investigate effects of environmental contaminants, Marine Environmental Research (2008), doi: 10.1016/ j.marenvres.2008.02.068

This is a PDF file of an unedited manuscript that has been accepted for publication. As a service to our customers we are providing this early version of the manuscript. The manuscript will undergo copyediting, typesetting, and review of the resulting proof before it is published in its final form. Please note that during the production process errors may be discovered which could affect the content, and all legal disclaimers that apply to the journal pertain. 


\title{
Use of immunofluorescence technique in cultured fibroblasts from
}

Mediterranean cetaceans as new "in vitro" tool to investigate

effects of environmental contaminants

\author{
Letizia Marsili*, Maria Cristina Fossi, Daniela Bucalossi, Serena \\ Porcelloni, Silvia Maltese, Silvia Casini
}

Department of Environmental Sciences “G. Sarfatti”, Siena University, Via Mattioli 4, 53100 Siena, ITALY.

\begin{abstract}
The aim of the present study was to propose the immunofluorescence technique in cultured fibroblasts from Mediterranean cetaceans as a new "in vitro" tool to explore the susceptibility of these marine mammals to different xenobiotic compounds. The cell lines were cultured from integument biopsies of free-ranging and stranded cetaceans (dead within $12 \mathrm{~h}$ ). Using the indirect immunofluorescence assay, we detected endogenous proteins induced by different contaminants. Here we present the method used for qualitative and quantitative evaluation of cytochromes P450 (CYP1A1 and CYP2B) induced by some POPs (DDTs and PCBs) and emerging contaminants (PBDEs) in fibroblast cell cultures of striped dolphin (Stenella coeruleoalba) and bottlenose dolphin (Tursiops truncatus). Immunofluorescence was quantified with a specially designed Olympus macro, DetectIntZ. A major result was the possibility of using this "in vitro" assay to quantify induction of endogenous proteins.
\end{abstract}




\section{ACCEPTED MANUSCRIPT}

Keywords: Mediterranean cetaceans; Fibroblast culture; Immunofluorescence technique; Xenobiotic contaminants

*Corresponding author: Email address: marsilil@unisi.it (L. Marsili)

Cetaceans, especially odontocetes, are particularly subject to chemical stress from xenobiotic compounds, as they accumulate large quantities of these contaminants (Marsili and Focardi, 1996; Marsili, 2000; Fossi and Marsili, 2003). Among the various techniques applied to integument biopsies, developed at the University of Siena (Fossi et al., 2003; Fossi et al., 2006), here we present the immunofluorescence technique in cultured fibroblasts as a new "in vitro" tool to explore the susceptibility of these marine mammals to different xenobiotics.

The development of a non-lethal sampling method to obtain viable tissue samples for fibroblast cell cultures from integument biopsies of free-ranging cetaceans was described in Marsili et al. (2000). Using the indirect immunofluorescence assay, we evaluated qualitative and quantitative presence of CYP1A1 and CYP2B induced by some POPs (DDTs and PCBs) and emerging contaminants (PBDEs) (Nims et al., 1998; Sierra-Santoyo et al., 2000; Meredith et al., 2003, Stoker et al., 2005). Cells were treated for 48 h with contaminants in sterile culture plates. Treatments were an OC mixture of Arochlor 1260, pp'DDT and pp'DDE in DMSO (0.05\%) at three doses: $1 \mu \mathrm{g} / \mathrm{ml}, 5 \mu \mathrm{g} / \mathrm{ml}$ and $25 \mu \mathrm{g} / \mathrm{ml}$, plus a DMSO (0.05\%) chemical control and a mixture (BDE-MXE, Wellington, Canada) containing 27 PBDEs, from mono- to deca-brominated, in nonane $(0.01 \mu \mathrm{g} / \mathrm{ml})$ at three doses: $0.1 \mu \mathrm{g} / \mathrm{ml}, 0.05 \mu \mathrm{g} / \mathrm{ml}$ and $0.01 \mu \mathrm{g} / \mathrm{ml}$, plus a nonane $(0.01 \mu \mathrm{g} / \mathrm{ml})$ chemical control. After fixing and extraction with methanol (4 min) and acetone ( $4 \mathrm{~min})$ at $-20^{\circ} \mathrm{C}$, they were washed three times in PBS for 10 min. Then we conducted a first reaction with primary polyclonal antibodies: goat anti rabbit cytochrome P450 1A1 and goat anti rabbit cytochrome P450 2B (Oxford Biochemical 
Research, Oxford, USA), diluted 1:500 for $1 \mathrm{~A} 1$ and 1:100 for $2 \mathrm{~B}$, for $2 \mathrm{~h}$. The cells were washed three times in PBS for 10 min and treated with the secondary antibody (Alexa Fluor 594 goat anti rabbit IgG (H+L)) labelled with red-fluorescent Alexa Fluor 594 dye, diluted 1:400, in the dark. The coverslips were again washed three times in PBS for 10 min. Fluorochrome was detected using $15 \mu \mathrm{l}$ per coverslip of a solution containing $40 \%$ CITIFLUOR, which is anti-fading solution that stabilizes fluorescence, and $60 \%$ PBS,

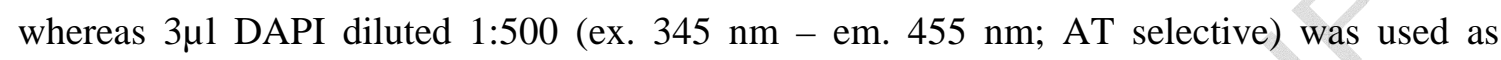
marker of chromatin for cell count. The reaction was read using an Olympus mod. BX41 fluorescence microscope with BX-URA2 HBO100W fluorescence device and U-MSWG2 dichroic cube excitation filter for green and U-MWU2 dichroic cube filter for UV. Images were obtained with an Olympus mod. DP-70 digital telecamera.

Immunofluorescence was quantified with a specially designed Olympus Soft Imaging Systems macro, DetectIntZ, which works with the image acquisition, processing and analysis system, analySIS^B (Olympus).

The image analysis procedure has the objective of quantifying, with an adimensional index generated for this purpose, the amount of Alexa Fluor 594 localized in the membrane of cytoplasmatic area of sample cells. The sample cells are imaged using DAPI and this image is presented to the operator for threshold selection of cytoplasmatic and nuclei Region of Interests (ROIs) across the field. The procedure then utilizes these ROIs to measure fluorescence intensity of Alexa Fluor 594 sample cell and summarizes the results in a worksheet. The system generates index values which are unitless until compared with other units, such as number of cells to obtain mean fluorescence per cell or the area in which it is calculated to obtain mean fluorescence per $\mathrm{mm}^{2}$. Images are all obtained with a magnification of 20X, a calibration of $0.65 \mu \mathrm{m} /$ pixel and a resolution of 1360 x 1024 x 8 pixel. Exposure times were maintained fixed while reading the CYP1A1 and CYP2B for each species and for 


\section{ACCEPTED MANUSCRIPT}

each treatment. A series of images of each slide was acquired so that a minimum of 250 cells/slide could be counted. The total fluorescence revealed by the program is divided by number of cells to obtain Arbitrary Unity of Fluorescence (AUF) per cell.

Nine slides for CYP1A1 and CYP2B were made for each culture, making a total of 18 slides for each toxicological treatment: of the nine, one was a blank (only primary and secondary antibodies), one was a secondary blank (only with secondary antibody), one was a chemical blank (treated with contaminant vehicle), two were for the first dose, two for the second dose and two for the third dose of contaminants. The blank enabled the natural presence of cytochromes in cultured fibroblasts to be checked. The secondary blank enabled validation of the dose of secondary antibody without cross reaction as the primary antibody was absent.

A major result was the possibility of using this "in vitro" assay to quantify induction of endogenous proteins such as CYP1A1 and CYP2B: the measurement of immunofluorescence intensities was used to determine protein levels and different induction phenomena correlated with the contaminant treatment.

In this paper we present the preliminary results of two odontocete species representative of the Mediterranean Sea: striped dolphin (Stenella coeruleoalba) and bottlenose dolphin (Tursiops truncatus). The fibroblasts were treated with the OC mixture (Fig. 1 and Table 1) and PBDE (Table 1). The results confirm the capability of this methodology to detect CYP1A1 and CYP2B induction in the striped dolphin, particularly at the highest treatment dose; only CYP2B induction with OC mixture at the intermediate dose and only CYP 1A1 with PBDE at the highest treatment dose was revealed in the bottlenose dolphin. 


\section{ACCEPTED MANUSCRIPT}

In conclusion, this methodology, applied to cultured fibroblasts of cetaceans, appears as a powerful "in vitro" technique to assess susceptibility of these marine mammals to different xenobiotic compounds.

\section{Acknowledgements}

Thanks to Laura Carletti for laboratory technical support, Prof. Tommaso Renieri, Fabrizio Cancelli and Centro Studi Cetacei onlus for sampling stranded animals. This project was supported by the Italian Ministry for Environment and Territory (Pelagos Project, ACCOBAMS Project).

\section{References}

Fossi, M.C., Marsili, L., Casini, S., and Bucalossi, D. (2006). Marine Enviromental Research, 62, 200-204.

Fossi, M.C., and Marsili, L. (2003). Pure and Applied Chemistry, 75, 2235-2247.

Fossi, M.C., Marsili, L., Neri, G., Natoli, A., Politi, E., and Panigada, S. (2003). Marine Pollution Bulletin., 46, 964-971.

Marsili, L. (2000). International Journal of the Environment and Pollution, 13, 416-452.

Marsili, L., Fossi, M. C., Neri, G., Casini, S., Gardi, C., Palmeri, S., et al. (2000). Marine Environmental Research, 50, 523-526.

Marsili, L., and Focardi, S. (1996). Environmental Pollution, 91, 1-9.

Meredith, C., Scott, M.P., Renwick, A.B., Price, R.J., and Lake, B.G. (2003). Xenobiotica, 33, 511-527.

Nims, R.W., Lubet, R.A., Fox, S.D., Jones, C.R., Thomas, P., Reddy, A.B., et al. (1998). Journal of Toxicology and Environmental Health, 53, 455-477. 
Sierra-Santoyo, A., Hernandez, M., Albores, A., and Cebrian, M. E. (2000). Toxicological Sciences, 54, 81-87.

Stoker, T.E., Cooper, R.L., Lambright, C.S., Wilson, V.S., Furr, J., Gray, L.E. (2005). Toxicology and Applied Pharmacology, 207, 78 - 88. 


\section{Figure caption}

Fig. 1. Immunofluorescence of CYP1A1 and CYP2B in cultured fibroblasts of striped dolphin and bottlenose dolphin treated with the OC mixture. A) and C): Striped dolphin fibroblasts: DAPI and Alexa Fluor 594 (Intensity = 133ms) images of DMSO and the three treatments. B) and D): Bottlenose dolphin fibroblasts: DAPI and Alexa Fluor 594 (Intensity = 50ms) images of DMSO and the three treatments. The immunofluorescence is expressed in Arbitrary Unity of Fluorescence (AUF) per cell. 


\section{ACCEPTED MANUSCRIPT}

Table 1.

Mean values of immunofluorescence of CYP1A1 and CYP2B revealed in cultured fibroblasts of striped dolphin and bottlenose dolphin treated with the OC and PBDE mixture. The immunofluorescence is expressed in index numbers respect to solvent control. Explication about treatment doses in the text.

\begin{tabular}{|c|c|c|c|c|}
\hline & CYP 1A1 & Organ & e mixture & \\
\hline & Solvent control & Dose 1 & Dose 2 & Dose 3 \\
\hline Striped dolphin & 100 & 93.16 & 90.42 & 166.92 \\
\hline Bottlenose dolphin & 100 & 63.00 & 96.48 & 81.43 \\
\hline & CYP 21 & Organo & mixture & \\
\hline & Solvent control & Dose 1 & Dose 2 & Dose 3 \\
\hline Striped dolphin & 100 & 94.07 & 107.86 & 219.28 \\
\hline Bottlenose dolphin & 100 & 88.56 & 136.23 & 85.72 \\
\hline & & YP 1A1 & & \\
\hline & Solvent con & Dose 1 & Dose 2 & Dose 3 \\
\hline Striped dolphin & 11 & 316.68 & 399.04 & 1304.62 \\
\hline Bottlenose dolphin & 100 & 71.14 & 102.50 & 131.92 \\
\hline & & YP 2B & & \\
\hline & Solvent control & Dose 1 & Dose 2 & Dose 3 \\
\hline Striped dolphin & 100 & 186.09 & 212.86 & 1776.41 \\
\hline Bottlenose dolphin & 100 & 71.46 & 69.24 & 94.15 \\
\hline
\end{tabular}


Fig.1

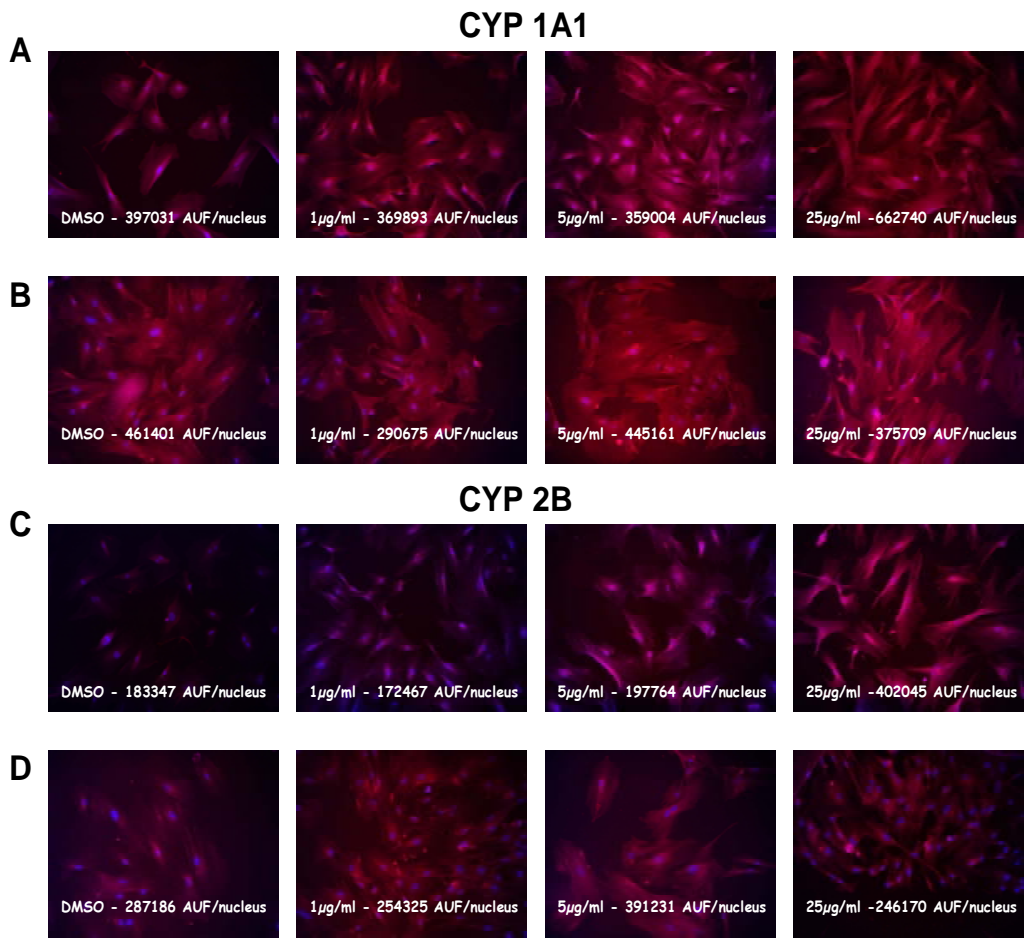

